\title{
Characterizing spatial and seasonal variability of carbon dioxide and water vapour fluxes above a tropical mixed mangrove forest canopy, India
}

\author{
Abhra Chanda ${ }^{1, *}$, Anirban Akhand ${ }^{1}$, Sudip Manna ${ }^{1}$, Sachinandan Dutta $^{1}$, \\ Sugata HazRA ${ }^{1}$, IndRANi DAS ${ }^{2}$ and $\mathrm{V}$ K DADHWAL ${ }^{3}$ \\ ${ }^{1}$ School of Oceanographic Studies, Jadavpur University, 188, Raja S. C. Mullick Road, \\ Kolkata 700 032, West Bengal, India. \\ ${ }^{2}$ Department of Botany, Midnapore College, Midnapore 721 101, West Bengal, India. \\ ${ }^{3}$ National Remote Sensing Centre, Department of Space, Government of India, \\ Balanagar, Hyderabad 500 037, Andhra Pradesh, India. \\ *Corresponding author.e-mail: abhrachanda1985@gmail.com
}

The above canopy carbon dioxide and water vapour fluxes were measured by micrometeorological gradient technique at three distant stations, within the world's largest mangrove ecosystem of Sundarban (Indian part), between April 2011 and March 2012. Quadrat analysis revealed that all the three study sites are characterized by a strong heterogeneity in the mangrove vegetation cover. At day time the forest was a sink for $\mathrm{CO}_{2}$, but its magnitude varied significantly from -0.39 to $-1.33 \mathrm{mg} \mathrm{m}^{-2} \mathrm{~s}^{-1}$. The station named Jharkhali showed maximum annual fluxes followed by Henry Island and Bonnie Camp. Day time fluxes were higher during March and October, while in August and January the magnitudes were comparatively lower. The seasonal variation followed the same trend in all the sites. The spatial variation of $\mathrm{CO}_{2}$ flux above the canopy was mainly explained by the canopy density and photosynthetic efficiency of the mangrove species. The $\mathrm{CO}_{2}$ sink strength of the mangrove cover in different stations varied in the same way with the $\mathrm{CO}_{2}$ uptake potential of the species diversity in the respective sites. The relationship between the magnitude of day time $\mathrm{CO}_{2}$ uptake by the canopy and photosynthetic photon flux was defined by a non-linear exponential curve $\left(\mathrm{R}^{2}\right.$ ranging from 0.51 to 0.60$)$. Water vapour fluxes varied between 1.4 and $69.5 \mathrm{mg} \mathrm{m}^{-2} \mathrm{~s}^{-1}$. There were significant differences in magnitude between day and night time water vapour fluxes, but no spatial variation was observed.

\section{Introduction}

Forest patches are considered to be a complex ecosystem by virtue of the variability in their composition and structure (Noe et al. 2011). These terrestrial ecosystems play a decisive role in regulating the atmospheric composition and hence the climate, by means of exchanging trace gases between the atmosphere and the biosphere
(Magnani et al. 2007; Misson et al. 2007). Every year, terrestrial plants fix one eighth of the atmospheric carbon dioxide $\left(\mathrm{CO}_{2}\right)$ by means of photosynthesis, while respiration, decay and soil organism activity return back a similar fraction, that is why, the key to accurately predict future levels of atmospheric $\mathrm{CO}_{2}$ is in understanding how the terrestrial biosphere and atmosphere exchange $\mathrm{CO}_{2}$ (Reich 2010). Recent estimates revealed that

Keywords. Carbon dioxide fluxes; water vapour fluxes; photosynthetic photon flux; spatial variation; mangrove forests; Sundarban. 
the terrestrial gross primary production (GPP) is the largest global $\mathrm{CO}_{2}$ flux $\left(\sim 123 \pm 8 \mathrm{Pg} \mathrm{C}_{\text {year }}{ }^{-1}\right)$ driving several ecosystem functions (Beer et al. 2010).

Micrometeorological techniques made continuous monitoring and frequent collection of data possible without disturbing the environment around the plant canopy (Baldocchi et al. 1988). Several endeavours have been undertaken to study the exchange dynamics of greenhouse gases over tropical terrestrial forests but a comparatively lesser attention has been paid on the mangrove forests at the land ocean boundary. Mangroves are one of the most productive and bio-diverse ecosystems developed along estuaries, sea coasts and river mouths in the tropical and subtropical intertidal zones. In general, the mangrove ecosystem including the below- and above-ground compartments act as sinks for $\mathrm{CO}_{2}$, but the water column and the sediment are largely found to emit the same (Borges et al. 2003). The present carbon burial rate within the mangrove systems has been assessed to be $\approx 18.4 \mathrm{Tg} \mathrm{C} \mathrm{yr}^{-1}$ based on the global mangrove cover of 160,000 km² (Bouillon et al. 2009).

Sundarban is the largest continuous stretch of mangrove forests of the world covering about $2.84 \%$ of the global mangrove area $\left(15 \times 10^{4} \mathrm{~km}^{2}\right)$ and having a unique bio-climatic zone in the land-ocean margin of the Bay of Bengal, out of which $40 \%$ lies within India and the rest in Bangladesh counterpart. In the year 1989, Sundarban Biosphere Reserve was constituted in the Indian Sundarban part, after the core area of the Sundarban Tiger Reserve, i.e., Sundarban National Park received the recognition of UNESCO World Heritage Site. Few studies were undertaken in the past in selected locations of the Sundarban deltaic system, which revealed dual character of this ecosystem in terms of source and sink for $\mathrm{CO}_{2}$. Mukhophadhya et al. (2000) carried out a short term survey in Jambu Island and observed the environment to be a sink for $\mathrm{CO}_{2}$ in the premonsoon season at a rate of $24 \times 10^{9} \mathrm{~kg} \mathrm{C}$ year $^{-1}$ while the same authors conducted another study at Lothian Island which reflected the source character with an emission rate of $1.51 \times 10^{6} \mathrm{mg}$ day $^{-1}$ (Mukhophadhya et al. 2001). Long term annual studies conducted later at the Lothian Island also confirmed a source character for $\mathrm{CO}_{2}$ as reported by Mukhophadhya et al. (2002), while at the same Lothian Island and Sajnekhali, Ganguly et al. (2008) observed a mean net influx of $-48.3 \mathrm{~g} \mathrm{~m}^{-2}$ day $^{-1}$ and total sink strength of $206 \mathrm{Gg}$ day $^{-1}$ was estimated for the entire reserve forest area $\left(4264 \mathrm{~km}^{2}\right)$. All the observations made so far tried to illustrate the holistic scenario of the ecosystem based on the results obtained from the particular study sites, but no prior attempts have been taken to discuss the spatial variability of the $\mathrm{CO}_{2}$ exchange within the same time frame in such a complex and heterogeneous gigantic mangrove ecosystem. The structure and functioning of mangrove forests are influenced by several physicochemical and bio-geographical factors like soil type, availability of water table, vapour pressure deficit, photosynthetic photon flux which again vary over different spatial and temporal scales (Duke et al. 1998). Apart from these factors, species diversity along with the species specific carbon uptake potential, determines the sink strength of a forest cover and canopy density also plays a crucial role behind the spatial variation of fluxes.

The present study aims to investigate the nature and magnitude of the atmosphere-biosphere $\mathrm{CO}_{2}$ and $\mathrm{H}_{2} \mathrm{O}$ fluxes above the forest canopy at three selected locations situated at the northern, middle and southern parts of the Indian Sundarbans. Micrometeorological techniques were implemented to carry out the investigation throughout a complete annual cycle. The study also strives to find out the relationship between the micrometeorological variables and the gas exchange, along with the effect of species composition, if any.

\section{Materials and methods}

\subsection{Site description}

The mangrove forest of Indian Sundarbans is situated between $21^{\circ} 32^{\prime}$ and $22^{\circ} 40^{\prime} \mathrm{N}$ latitudes and between $88^{\circ} 05^{\prime}$ and $89^{\circ} \mathrm{E}$ longitudes comprising an area of $9630 \mathrm{~km}^{2}$ out of which $4264 \mathrm{~km}^{2}$ is under the arena of reserve forest. It extends till the Bay of Bengal towards south and stretches up to the Dampier-Hodges line in the north. The climate in this part of the continent is grossly demarcated as monsoon (June-September), postmonsoon (October-January) and pre-monsoon (February-May). In order to understand the spatial variability in $\mathrm{CO}_{2}$ and $\mathrm{H}_{2} \mathrm{O}$ dynamics above the forest canopy, flux measurements were carried out at three sites located at the northern, middle and southern parts of the Indian Sundarbans (figure 1). Jharkhali Island $\left(22^{\circ} 01^{\prime} 16^{\prime \prime} \mathrm{N}, 88^{\circ} 41^{\prime} 4.75^{\prime \prime} \mathrm{E}\right)$ at the confluence of Bidya and Herobhanga rivers (northern station), Bonnie Camp $\left(21^{\circ} 49^{\prime} 47.87^{\prime \prime} \mathrm{N}\right.$, $88^{\circ} 37^{\prime} 22.33^{\prime \prime} \mathrm{E}$ ) almost $30 \mathrm{~km}$ downstream (middle station) from Jharkhali and Henry Island $\left(21^{\circ} 34^{\prime} 27.11^{\prime \prime} \mathrm{N}, 88^{\circ} 17^{\prime} 34.06^{\prime \prime} \mathrm{E}\right)$ at the southernmost tip of the Sundarbans (southern station) were chosen for this study (hereafter referred to as Stn1, Stn2 and Stn3, respectively). Out of these three stations, Stn3 has a tower of $16 \mathrm{~m}$ height and the rest two have towers of $20 \mathrm{~m}$ height. 


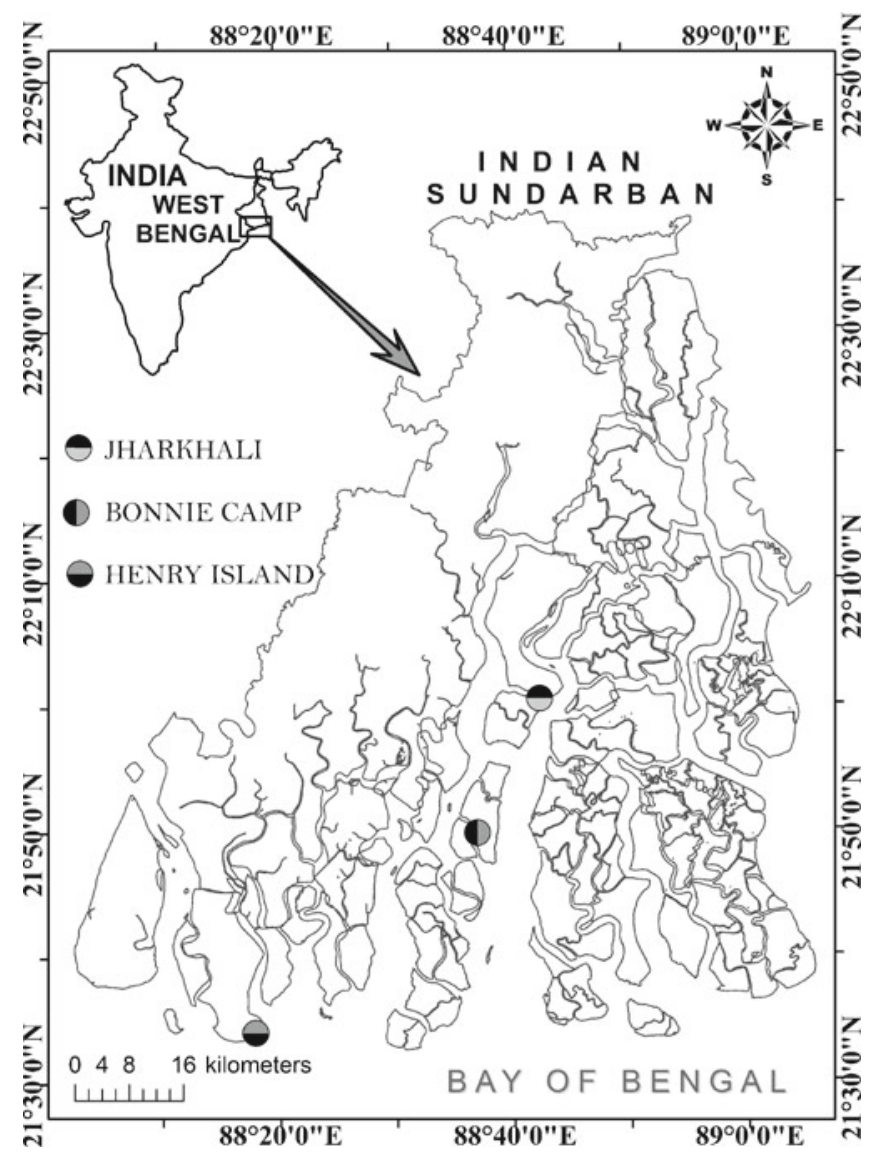

Figure 1. The location of the study sites shown in the map of Indian Sundarbans.

In Stn1, Avicenia marina (Forssk.) Vierh. together with Avicenia alba Blume dominate the canopy cover, while Excoecaria agallocha L., Phoenix paludosa Roxb. and Bruguiera gymnorrhiza are also found in patches. A large abundance of Phoenix paludosa is observed in Stn2 followed by Avicenia marina with few patches of Aegiceras corniculatum and Agialites rotundifolia. The top canopy layer in Stn3 is mainly comprised of Avicenia officinalis L., other dominant species in the lower strata are Aegiceras corniculatum (L.) Blanco and Agialites rotundifolia Roxb. In the interior parts, Avicenia alba and Bruguiera gymnorrhiza (L.) Lam. are also found to thrive.

\subsection{Instrumentation and sampling strategy}

All observations were made in every month at each site, for a continuous 24 hour diurnal cycle, from April 2011 to March 2012. In order to examine the diurnal variation, all the data were logged at every 1 hour interval. $\mathrm{CO}_{2}$ and $\mathrm{H}_{2} \mathrm{O}$ fluxes were monitored at half hourly intervals and averaged to 1 hour. Difficulties in accessing Stn2 all round the year has compelled us to study this site bimonthly. In Stn3, flux calculations were made from the difference in concentration at 6 and $16 \mathrm{~m}$ respectively, whereas, in the other two stations fluxes were calculated from the difference in concentration between 10 and $20 \mathrm{~m}$. In all the cases, the topmost forest canopy layer was well below the lower height from which the air samples were drawn. Stn1 had a uniform canopy height of 8-9 m, while the other two stations had a comparatively lower canopy height ranging between 4 and $5 \mathrm{~m}$, as Stn1 is dominated with species which can grow taller compared to those dominant in Stn2 and Stn3. Air samples from the respective measuring heights of the tower were pumped and passed through at the rate of 0.5 litre $\mathrm{min}^{-1}$ (with the help of a portable air sampler) to the closed path LI-840A $\mathrm{CO}_{2} / \mathrm{H}_{2} \mathrm{O}$ Gas Analyzer (Li-Cor, Inc. USA) to get the ambient concentration of $\mathrm{CO}_{2}$ (in ppm). In order to minimise the effect of fluctuations, a 5minute average for $\mathrm{CO}_{2}$ values were used to calculate the flux. The analyzer was calibrated before and after the completion of each diurnal cycle with the help of three gases, one having $\mathrm{CO}_{2}$-free air and the other two having a certified reference standard of known concentration (300 and 600 ppm in $\mathrm{N}_{2}$ medium) of $\mathrm{CO}_{2}$ (Indian Refrigeration Stores, Kolkata, West Bengal, India). The relative uncertainties (standard deviation relative to mean value) were observed to be \pm 0.04 for $\mathrm{CO}_{2}$ concentration measurements and \pm 0.09 for $\mathrm{H}_{2} \mathrm{O}$ concentrations.

Micrometeorological parameters like air temperature, atmospheric pressure, relative humidity, wind velocity and its direction were recorded with the help of weather stations (La Crosse Technology, WS-2350) mounted at the respective towers. The precision of measurements are $0.1^{\circ} \mathrm{C}$ for air temperature, $1 \mathrm{~m}$ bar for atmospheric pressure, $1 \%$ relative humidity and $0.1 \mathrm{~m} \mathrm{~s}^{-1}$ for wind velocity, respectively. The photosynthetic active radiation (PAR) is measured with the help of a PAR Sensor (LI-190, Li-Cor, Inc. USA) fitted at the top of the towers. The precision of measurement was $0.1 \mu \mathrm{mol}$ $\mathrm{m}^{-2} \mathrm{~s}^{-1}$. In Stn1 and Stn2, the fetch of the forest stand extends to almost $1 \mathrm{~km}$ in all directions from the tower, but in Stn3 there is a void space in the forest patch in the south-south eastern section. Flux measurement was skipped for this site when wind had a direction between $105^{\circ}$ and $155^{\circ}$ from that end.

\subsection{Flux calculations}

The exchange of trace gases were calculated by micrometeorological methods (gradient technique), using the formula:

$$
F_{\mathrm{CO}_{2}}=K c \cdot \Delta C_{i}
$$

where $F_{\mathrm{CO}_{2}}$ denotes the atmosphere-biosphere flux $\left(\mathrm{mg} \mathrm{m} \mathrm{m}^{-2} \mathrm{~s}^{-1}\right), \Delta C_{i}$ is the difference in 
concentration of trace gases $\left(\mathrm{mg} \mathrm{m}^{-3}\right)$ at the respective heights mentioned above and $K c$ is the exchange velocity which is further defined as:

$$
K c=\frac{1}{\left(R_{a}+R_{s}\right)},
$$

where $R_{a}$ and $R_{s}$ stand for aerodynamic and surface layer resistance, respectively (Barrett 1998). Fluxes towards the canopy are noted with a negative sign; while fluxes away from the canopy towards the atmosphere are given with a positive sign.

Surface layer resistance $\left(R_{s}\right)$ was calculated from surface transfer function $\left(B^{-1}\right)$ and friction velocity $(u *)$, following the relations:

$$
\mathrm{k} B^{-1}=2\left(\frac{K}{D_{c}}\right)^{2 / 3}
$$

and

$$
R_{s}=\frac{B^{-1}}{u *}
$$

where $\mathrm{k}$ is the Von Karman constant, $K$ is thermal diffusivity of air and

$D_{c}$ (molecular diffusivity) $=0.115\left(T_{2} / 273\right)^{1.5}$,

where $T_{2}$ is the temperature at $20 \mathrm{~m}$ height (Wesely and Hicks 1977). Friction velocity

$$
(u *)=\mathrm{k}\left(u_{10}-u_{20}\right) / 0.693,
$$

where $u_{10}$ and $u_{20}$ are wind speed at 10 and $20 \mathrm{~m}$ height respectively. The equation

$$
R_{a}=\left(\ln \left(\frac{Z}{Z_{0}}\right)-\Psi_{m}\right) / \mathrm{k} u *
$$

is used to calculate the aerodynamic resistance where $Z_{0}$ represents the roughness length and $\Psi_{m}$ stands for the atmospheric stability correction function (Wesely and Hicks 1977). $Z_{0}$ was obtained from the y-intercept $\left(\ln Z_{0}\right)$ of the straight line from the plot of $\ln Z$ vs. $u$. The atmospheric correction functions were evaluated based on the output of $Z / L$ where $L$ stands for the Obukhov scale length.

Obukhov scale length is a metric of atmospheric stability and is approximately the height at which buoyancy starts to dominate over mechanically generated turbulence.

$$
L=-\left(u * \theta_{v}\right) / \mathrm{k} \cdot g\left(\omega^{\prime} \theta_{v}^{\prime}\right)_{s},
$$

where $\theta_{v}$ is the mean virtual potential temperature. The potential temperature for air is generally expressed as:

$$
\theta=T\left(P_{0} / P\right)^{R / C p}
$$

where $T$ is the absolute temperature of the parcel of air, $R$ and $C_{p}$ are the universal gas constant and specific heat capacity at constant pressure of air, respectively. $P$ stands for the instantaneous atmospheric pressure and $P_{0}$ is the standard reference pressure taken as $1000 \mathrm{~m}$ bar. Using the similarity theory approximation $\left(\omega^{\prime} \theta_{v}^{\prime}\right)_{s}=-u * \theta *$, where $\theta *$ is proportional to $\theta_{10}-\theta_{20}$, i.e., the vertical difference in potential virtual temperature, the Obukhov length reduces to

$$
L=\left(\begin{array}{ll}
u *^{2} & \theta_{v}
\end{array}\right) / \mathrm{k} \cdot g \theta * .
$$

For stable conditions (i.e., $Z / L>0$ ),

$$
\Psi_{m}=4.7 Z / L
$$

and for unstable condition (i.e., $Z / L<0$ ),

$$
\begin{aligned}
\Psi_{m}= & -2 \ln (1+x) / 2-\ln \left(1+x^{2}\right) / 2 \\
& +2 \tan ^{-1}(x)-\pi / 2,
\end{aligned}
$$

where $x=(1-15 Z / L)^{1 / 4}$ (Stull 1988). In order to avoid possible underestimation of the flux in stable conditions during night, the effect of low friction velocity was examined (figure 2). Below $u^{*}$ values of $0.30 \mathrm{~m} \mathrm{~s}^{-1}$, a decreasing trend in the flux was observed. Therefore only values above this threshold were considered valid.

Sensible heat flux is calculated according to the relation

$$
H=\rho_{t} . C p\left(T_{10}-T_{20}\right) /\left(R_{a}+R_{s}\right)
$$

and water vapour flux $E$ was computed according to the relation

$$
E=\rho_{t} /(8 / 5) p\left(P_{\mathrm{H}_{2} \mathrm{O}(10 \mathrm{~m})}-P_{\mathrm{H}_{2} \mathrm{O}(20 \mathrm{~m})}\right),
$$

where partial pressure of water vapour

$$
P_{\mathrm{H}_{2} \mathrm{O}}=(h / 100) P_{0},
$$

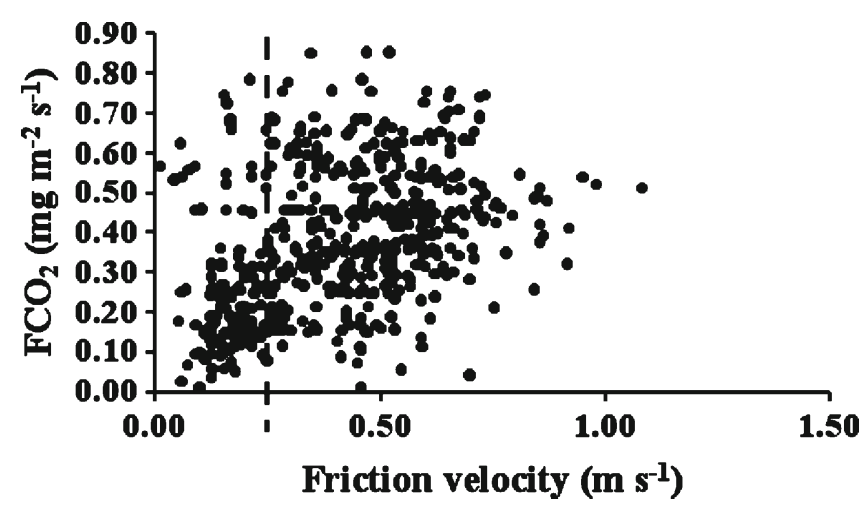

Figure 2. Night time efflux of $\mathrm{CO}_{2}\left(\mathrm{~F}_{\mathrm{CO}_{2}}\right)$ as a function of friction velocity $(u *)$ during the study period comprising the data acquired from the three towers. The vertical dashed line represents the threshold below which the flux had a decreasing trend. 
$h$ being the relative humidity and $P_{0}$ is the vapour pressure at a given temperature obtained from the relation

$$
\begin{aligned}
\ln P_{0}= & -0.493048+0.07263769 t \\
& -0.000294549 t^{2}+9.79832 \times 10^{-7} t^{3} \\
& -1.86536 \times 10^{-9} t .
\end{aligned}
$$

Latent heat flux is evaluated as per the relation

$$
H_{L}=E L,
$$

where $L$ is the latent heat of vapourization (Ganguly et al. 2008).

During static conditions, i.e., when wind velocity were found to be near zero, the molecular diffusion flux was also calculated by applying Fick's first law and using the relation

$$
F_{\mathrm{CO}_{2}}=-D_{d} \mathrm{~d} C / \mathrm{d} Z,
$$

where $D_{d}$ is the inter-diffusion coefficient for $\mathrm{CO}_{2}$ and $\mathrm{d} C / \mathrm{d} Z$ is the concentration gradient along the height. $D_{d}$ is computed according to the formula

$$
D_{d}=1.325+0.009 t\left({ }^{\circ} \mathrm{C}\right)
$$

(Lerman 1979). To identify the layer of frictional influence adjoining the earth's surface, the height of Planetary Boundary Layer (PBL) was calculated using the formula

$$
h=0.25 u * / f,
$$

given $f=2 \Omega \sin \Phi$ is the Coriolis parameter, $\Omega$ and $\Phi$ being the rotational speed of the earth and latitude, respectively (Ganguly et al. 2008).

\subsection{Quadrat analysis}

The species composition of the sites was studied by performing quadrat analysis in Stn1 and Stn3. It could not be done in Stn2, as it is situated in the core area of Sundarban Tiger Reserve (STR); entry in the forest area was strictly prohibited due to safety reasons. In Stn1 and Stn3, quadrat surveys were conducted in the months of October and February in 10 plots $(10 \mathrm{~m} \times 10 \mathrm{~m})$ at each site, randomly covering the fetch of the vegetation cover. By means of species count, the dominant species of the sites were marked and their relative abundance was calculated from the composite average of all the quadrat plots. Since the main focus of the present study was related to canopy photosynthesis, special care was taken to include only those species (in computing relative abundance) whose canopy lied in the top layer receiving uninterrupted sunlight. The plants lying in the lower strata were excluded from the species count. The canopy density was measured with the help of a spherical densiometer (Robert E Lemmon, Model A, Forest Densiometers).

\section{Results and discussion}

\subsection{Meteorological conditions}

The seasonal mean values of the micrometeorolog-

\begin{tabular}{|c|c|c|c|}
\hline Parameters & Pre-monsoon & Monsoon & Post-monsoon \\
\hline \multicolumn{4}{|l|}{ Air temperature $\left({ }^{\circ} \mathrm{C}\right)$} \\
\hline $10 \mathrm{~m}$ & $30.7 \pm 3.2$ & $29.2 \pm 1.8$ & $22.3 \pm 5.8$ \\
\hline $20 \mathrm{~m}$ & $28.7 \pm 3.6$ & $28.4 \pm 1.6$ & $20.9 \pm 4.7$ \\
\hline \multicolumn{4}{|l|}{ Atmospheric pressure (mb) } \\
\hline $10 \mathrm{~m}$ & $1012 \pm 3$ & $1007 \pm 7$ & $1017 \pm 2$ \\
\hline $20 \mathrm{~m}$ & $1010 \pm 2$ & $1006 \pm 5$ & $1013 \pm 2$ \\
\hline \multicolumn{4}{|l|}{ Wind velocity $\left(\mathrm{m} \mathrm{s}^{-1}\right)$} \\
\hline $10 \mathrm{~m}$ & $2.09 \pm 1.69$ & $1.63 \pm 1.26$ & $1.21 \pm 1.05$ \\
\hline $20 \mathrm{~m}$ & $3.11 \pm 1.54$ & $2.50 \pm 1.39$ & $2.19 \pm 0.93$ \\
\hline Wind direction & $150^{\circ}-185^{\circ}$ & $120^{\circ}-220^{\circ}$ & $300^{\circ}-30^{\circ}$ \\
\hline Friction velocity $\left(\mathrm{m} \mathrm{s}^{-1}\right)$ & $0.55 \pm 0.36$ & $0.61 \pm 0.17$ & $0.48 \pm 0.43$ \\
\hline $\mathrm{Z}_{0}(\mathrm{~m})$ & $1.23 \pm 0.45$ & $2.01 \pm 0.82$ & $1.93 \pm 0.41$ \\
\hline Planetary boundary layer (m) & $2748 \pm 215$ & $2541 \pm 359$ & $2248 \pm 154$ \\
\hline Photosynthetic photon flux $\left(\mathrm{mol} \mathrm{m}{ }^{-2} \mathrm{~d}^{-1}\right)$ & $82.7 \pm 5.84$ & $72.8 \pm 4.58$ & $78.56 \pm 9.65$ \\
\hline Relative humidity (\%) & $77.0 \pm 15.2$ & $87.0 \pm 9.4$ & $68.5 \pm 12.5$ \\
\hline $\mathrm{CO}_{2}$ concentration $(\mathrm{ppm})$ & $382.54 \pm 14.26$ & $379.25 \pm 9.55$ & $372.58 \pm 7.56$ \\
\hline Bowen ratio (day time) & $0.68 \pm 0.12$ & $0.81 \pm 0.17$ & $0.94 \pm 0.05$ \\
\hline Bowen ratio (night time) & $0.42 \pm 0.06$ & $0.29 \pm 0.12$ & $0.34 \pm 0.17$ \\
\hline
\end{tabular}
ical parameters are given in table 1 . The mean \pm standard deviations have been tabulated from the composite data acquired from all the three towers. The air temperature above the canopy (at $15 \mathrm{~m}$

Table 1. Seasonal variation of atmospheric and micrometeorological variables along with the $\mathrm{CO}_{2}$ concentrations (averaged over the three stations studied). 
height) had a range of $13.2^{\circ}$ to $39.8^{\circ} \mathrm{C}$ throughout the complete annual cycle. The lowest temperatures occurred in December-January and the highest in May-June. Diurnal maximum temperature difference of $14.5^{\circ} \mathrm{C}$ was observed in the month of January and a minimum of $4.2^{\circ} \mathrm{C}$ in May. Stable conditions with inversion of ambient temperature were observed during the midnight and late evening hours of post-monsoon and pre-monsoon seasons. Near neutral conditions were hard to trace as the switch over from unstable to stable atmospheric conditions occurred very rapidly. The average wind velocity was found highest during the pre-monsoon season. Owing to the effect of the nor'westers it attained maximum during MarchApril. The land and sea breeze phenomenon was also prominent during this time of the year. On the other hand, the wind velocities used to drop down to zero during the cold winter nights (postmonsoon season). The friction velocity $(u *)$ had an annual average of $0.62 \mathrm{~m} \mathrm{~s}^{-1}$; values below $0.25 \mathrm{~m} \mathrm{~s}^{-1}$ occurred only $15 \%$ of the total time but $37 \%$ of the night time. The roughness length $\left(\mathrm{Z}_{0}\right)$ varied between 0.42 and $3.91 \mathrm{~m}$; comparatively higher values were observed in Stn1 where the average height of mangrove plants were taller than that found in Stn2 and Stn3. The photosynthetic photon flux had a minimum in August (68.7 $\mathrm{mol} \mathrm{m}^{-2} \mathrm{~d}^{-1}$ ) due to the interference posed by dark rain clouds and it was found maximum in May $\left(87.2 \mathrm{~mol} \mathrm{~m}^{-2} \mathrm{~d}^{-1}\right)$. The rainfall during the study period had been extremely erratic with an annual total of $1950 \mathrm{~mm}$ (data acquired from India Meteorological Department). Torrential downpours were observed during June and August, whereas several post-monsoon months were absolutely devoid of any rainfall (figure 3 ).
3.2 Diurnal to seasonal $\mathrm{CO}_{2}$ and $\mathrm{H}_{2} \mathrm{O}$ fluxes

The mean annual concentration of $\mathrm{CO}_{2}$ above the forest canopy was $379.24 \pm 13.14 \mathrm{ppm}(20 \mathrm{~m}$ from ground level) with lowest observed in postmonsoon season and highest during the monsoon (table 1). Spatially the $\mathrm{CO}_{2}$ mixing ratio in the three sites did not vary much. In Stn1 its annual mean was $382.15 \pm 7.68 \mathrm{ppm}$ and in Stn3 it was $383.04 \pm 6.87 \mathrm{ppm}$, but in Stn2 it was comparatively less $(378.95 \pm 6.56 \mathrm{ppm})$, though the variation was not statistically significant. This might be attributed to the fact that $\mathrm{Stn} 2$ is situated deep inside the core area far away from any kind of anthropogenic activities, hence the $\mathrm{CO}_{2}$ mixing ratio here gets diluted compared to Stn1 and Stn3, where automobiles run in near distances. On an average, there was a $9.8 \%$ increase of $\mathrm{CO}_{2}$ concentration by night time. The exchange of $\mathrm{CO}_{2}$ is composed by two types of fluxes: influx towards the canopy due to plant photosynthesis (negative $\mathrm{CO}_{2}$ fluxes) and efflux from the canopy towards atmosphere due respiration at night (positive $\mathrm{CO}_{2}$ fluxes) (Aubinet et al. 2005). In the summer months (April to June) negative $\mathrm{CO}_{2}$ fluxes were recorded from early morning $(06: 00 \mathrm{~h})$ to late evening $(18: 15 \mathrm{~h})$, while in the winter season the effective day length was much smaller and the canopy behave as a sink for $\mathrm{CO}_{2}$ between 07:15 and 16:45 $\mathrm{h}$ local time. In the pre-monsoon and post-monsoon months, a steady increase of day time $\mathrm{CO}_{2}$ flux was noted with the increase in photosynthetic photon flux and it attained a maximum during $12: 30$ to $13: 15 \mathrm{~h}$, but no such trend was observed during the monsoon (figure 4). In the monsoon season, the intensity of PAR and hence the photosynthetic rate was dependent on

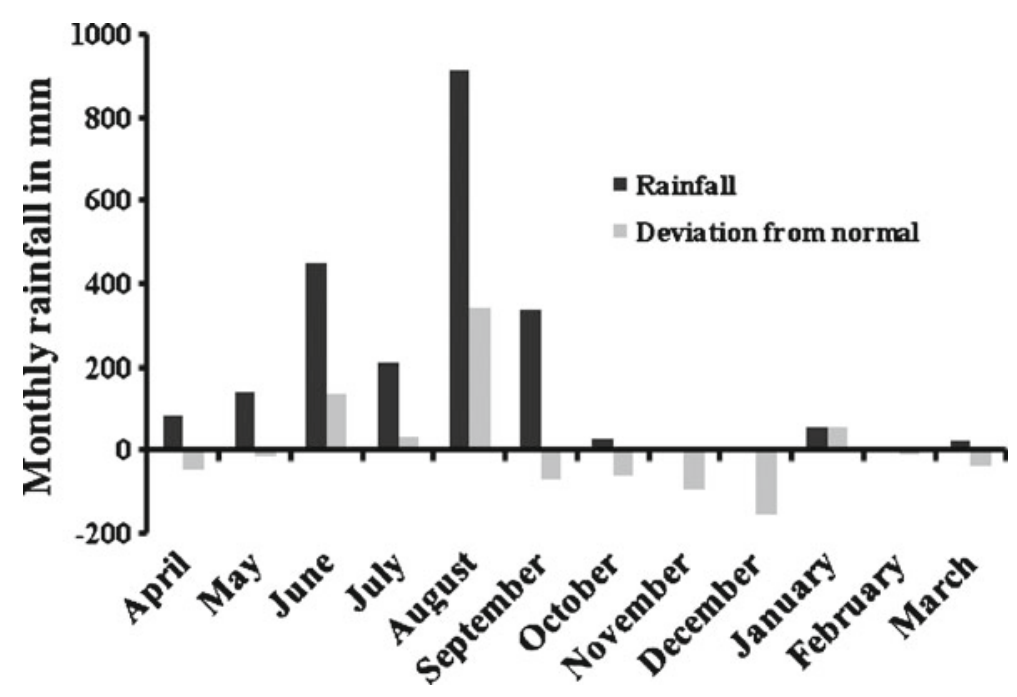

Figure 3. Month-wise precipitation ( $\mathrm{mm}$ ) and deviation from normal $(\mathrm{mm})$ during the study period recorded at the nearest meteorological centre (India Meteorological Department). 

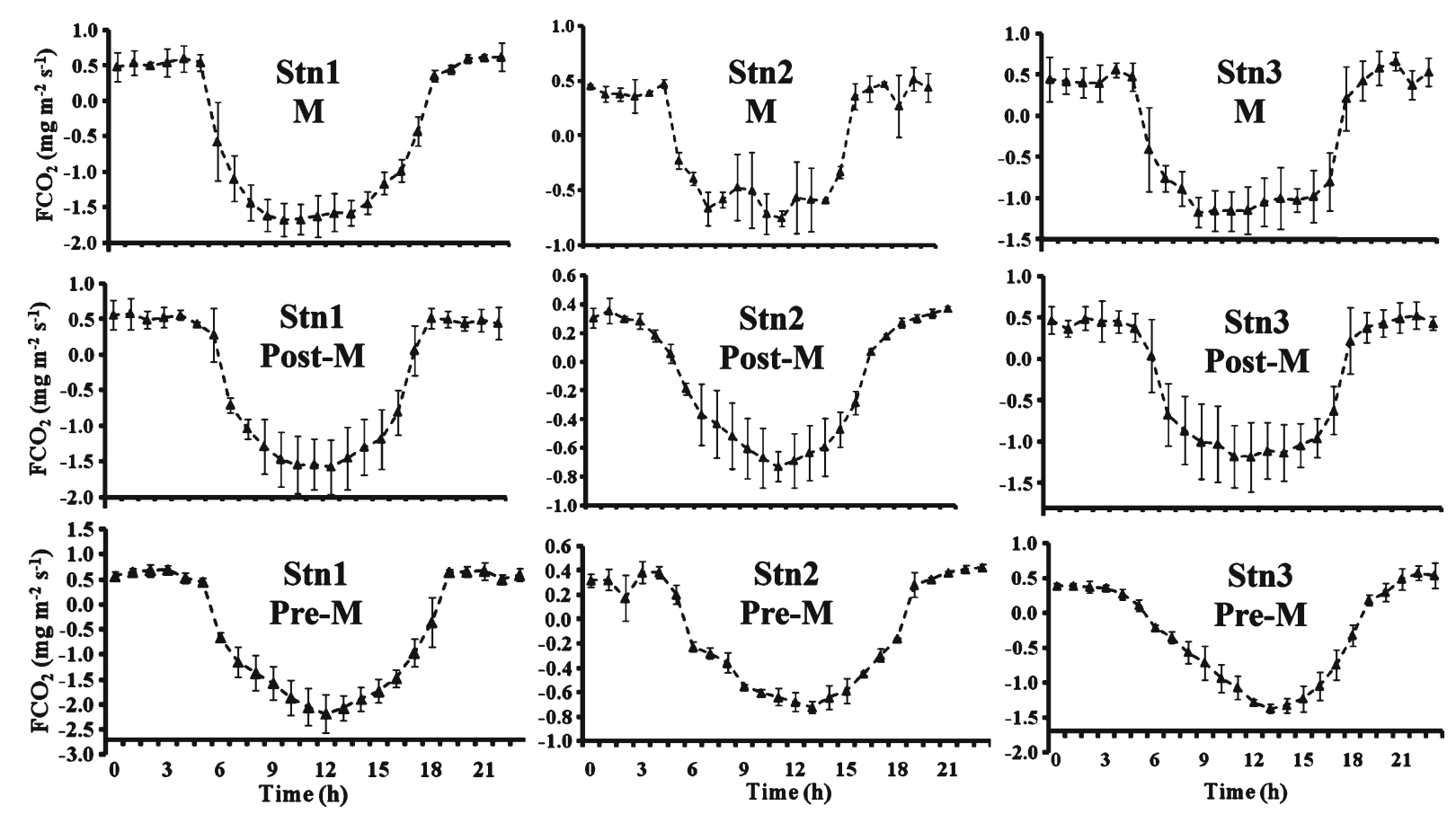

Figure 4. Mean daily cycles of $\mathrm{CO}_{2}$ flux $\left(\mathrm{F}_{\mathrm{CO}_{2}}\right)$ above the forest canopy in the three stations (Stn1, Stn2 and Stn3) during the pre-monsoon (Pre M), monsoon (M) and post-monsoon (Post M) seasons. The vertical bars denote the standard deviation from the mean of the corresponding hourly fluxes.

the cloud cover rather than on the time of day. Despite the fact that highest photosynthetic photon flux was recorded in the month of May, the highest average day time $\mathrm{CO}_{2}$ flux was observed in March (table 2). In the beginning of the postmonsoon season an average increase in $\mathrm{CO}_{2}$ uptake is noticed. This may be due to the increased canopy density with the formation of new leaves after the heavy showers of June and July (monsoonal rain). The night time $\mathrm{CO}_{2}$ flux had no significant seasonality. The largest uncertainties in the presented results are related to the determination of night time fluxes especially during cold winter months (having friction velocity as low as $0.07-0.18 \mathrm{~m} \mathrm{~s}^{-1}$ ). The computed molecular diffusion fluxes ranged between 0.13 and $0.26 \mathrm{mg} \mathrm{m}^{-2} \mathrm{~s}^{-1}$, which was comparatively much lower than that observed during conditions having friction velocity $>0.3 \mathrm{~m} \mathrm{~s}^{-1}$. Under these circumstances the estimated flux values were substituted by values calculated from the overall relation between night time flux and ambient temperature as per Lindroth et al. (1998). In the warmer months, the night time fluxes were comparatively higher than that found in winter. In

Table 2. Monthly average of $\mathrm{CO}_{2}$ influx towards canopy (during day time) and efflux of CO $\mathrm{O}_{2}$ away from the canopy (during night time) in the three stations.

\begin{tabular}{|c|c|c|c|c|c|c|}
\hline \multirow[b]{2}{*}{ Month } & \multicolumn{2}{|c|}{ Stn1 } & \multicolumn{2}{|c|}{ Stn2 } & \multicolumn{2}{|c|}{ Stn3 } \\
\hline & Day & Night & Day & Night & Day & Night \\
\hline April & $-1.42 \pm 0.57$ & $0.62 \pm 0.10$ & & & $-0.82 \pm 0.40$ & $0.40 \pm 0.16$ \\
\hline May & $-1.57 \pm 0.50$ & $0.56 \pm 0.07$ & $-0.57 \pm 0.07$ & $0.38 \pm 0.12$ & $-0.91 \pm 0.35$ & $0.41 \pm 0.10$ \\
\hline June & $-1.47 \pm 0.39$ & $0.46 \pm 0.15$ & & & $-0.95 \pm 0.18$ & $0.32 \pm 0.14$ \\
\hline July & $-1.33 \pm 0.40$ & $0.46 \pm 0.11$ & $-0.46 \pm 0.17$ & $0.37 \pm 0.15$ & $-0.87 \pm 0.41$ & $0.45 \pm 0.19$ \\
\hline August & $-1.22 \pm 0.19$ & $0.57 \pm 0.09$ & & & $-0.85 \pm 0.32$ & $0.60 \pm 0.15$ \\
\hline September & $-1.51 \pm 0.43$ & $0.59 \pm 0.17$ & $-0.61 \pm 0.21$ & $0.41 \pm 0.09$ & $-0.97 \pm 0.33$ & $0.51 \pm 0.14$ \\
\hline October & $-1.61 \pm 0.45$ & $0.62 \pm 0.12$ & & & $-1.13 \pm 0.42$ & $0.48 \pm 0.12$ \\
\hline November & $-1.34 \pm 0.34$ & $0.48 \pm 0.14$ & $-0.70 \pm 0.15$ & $0.32 \pm 0.16$ & $-1.02 \pm 0.30$ & $0.58 \pm 0.11$ \\
\hline December & $-1.16 \pm 0.29$ & $0.51 \pm 0.07$ & & & $-0.81 \pm 0.16$ & $0.46 \pm 0.07$ \\
\hline January & $-0.92 \pm 0.28$ & $0.34 \pm 0.06$ & $-0.40 \pm 0.14$ & $0.23 \pm 0.10$ & $-0.50 \pm 0.27$ & $0.25 \pm 0.06$ \\
\hline February & $-1.37 \pm 0.38$ & $0.64 \pm 0.13$ & & & $-0.74 \pm 0.41$ & $0.27 \pm 0.10$ \\
\hline March & $-1.79 \pm 0.67$ & $0.55 \pm 0.16$ & $-0.64 \pm 0.10$ & $0.42 \pm 0.05$ & $-1.23 \pm 0.44$ & $0.39 \pm 0.20$ \\
\hline
\end{tabular}


winter mornings, especially after long nights having very stable conditions with the formation of fog just above the forest canopy, positive $\mathrm{CO}_{2}$ flux was observed even after the appearance of sun rays above the horizon. This shows the release of stored $\mathrm{CO}_{2}$ as observed by Pilegaard et al. (2001).

The water vapour flux in an ecosystem is principally the sum of evaporation and transpiration with the surface condensation of water vapour being subtracted from it (Meiresonne et al. 2003). The water vapour fluxes were found positive throughout the year but there were significant differences in their magnitude between day and night time (figure 5). During day time the fluxes increased steadily with the increment in ambient temperature and attained the maximum during 11:30-12:15 h. The lowest water vapour fluxes $\left(1.3 \mathrm{mg} \mathrm{m}^{-2} \mathrm{~s}^{-1}\right)$ were observed during the midnights of monsoon season whereas in the scorching noon of summer it was as high as $69.5 \mathrm{mg} \mathrm{m}^{-2} \mathrm{~s}^{-1}$. In the pre-monsoon season, the difference between mean day and night time evapotranspiration rates was observed to be the least $\left(20.5 \mathrm{mg} \mathrm{m}^{-2} \mathrm{~s}^{-1}\right)$.

\subsection{Spatial variability of $\mathrm{CO}_{2}$ and $\mathrm{H}_{2} \mathrm{O}$ fluxes}

Scrutinizing the dataset acquired from all the sites throughout the year, it is found that $42 \%$ of the night time data were not of good quality, but $83 \%$ of the day time data did pass through the quality filters set on the basis of threshold friction velocity and proper wind direction. One-way ANOVA on the diurnal averaged $\mathrm{CO}_{2}$ fluxes from the three towers reveal significant differences in magnitude $(F=8.2, p<0.005, n=246)$. The mean $\mathrm{CO}_{2}$ uptake was maximum in $\operatorname{Stn} 1\left(-1.33 \mathrm{mg} \mathrm{m}^{-2} \mathrm{~s}^{-1}\right)$, followed by Stn3 $\left(-0.88 \mathrm{mg} \mathrm{m}^{-2} \mathrm{~s}^{-1}\right)$. An annual mean $\mathrm{CO}_{2}$ influx of $-0.39 \mathrm{mg} \mathrm{m} \mathrm{m}^{-2} \mathrm{~s}^{-1}$ was observed in Stn2. Ray et al. (2011) observed a net community $\mathrm{CO}_{2}$ exchange rate of $1.00 \pm$ $0.66 \mathrm{mg} \mathrm{m}^{-2} \mathrm{~s}^{-1}$ working in several sites of Sundarban. The number of valid data in Stn2 was almost half in comparison to the other two sites, even then the monthly variation was found statistically significant $(F=9.68, p=0.000, n=144)$. Though the $\mathrm{CO}_{2}$ fluxes were of varying magnitude, the average water vapour fluxes as well as the sensible and latent heat fluxes did not show any difference among the three towers as observed by Mildenberger et al. (2009). The measurement of flux at Stn3 were made at different heights compared to the other two sites, but it is considered to have no influence on the difference of $\mathrm{CO}_{2}$ fluxes, because with in the PBL fluxes are nonvariant with height, if the fetch remains uniform (Foken 2006).

Latent heat flux was found to be the dominant component as the measured Bowen ratio's showed
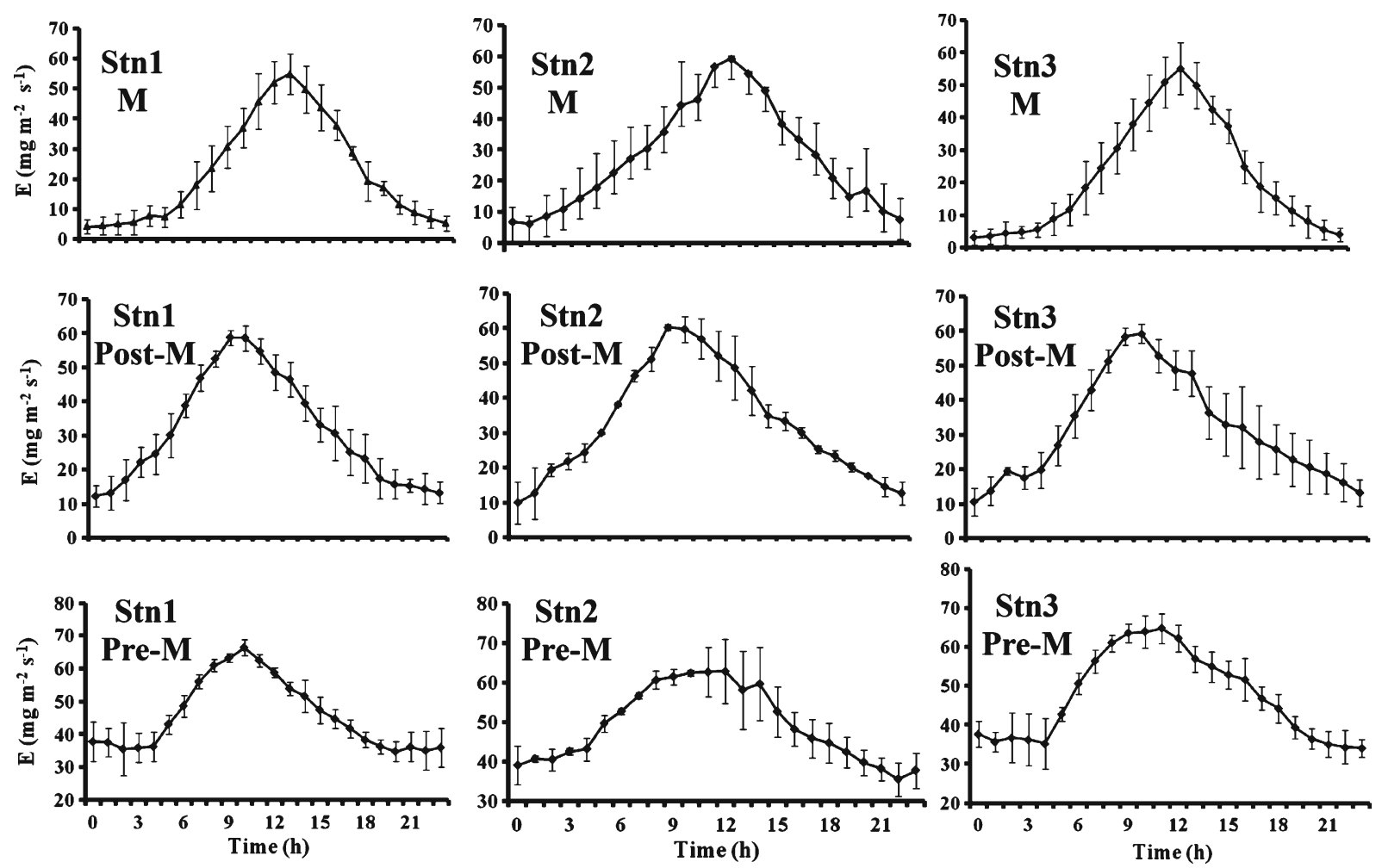

Figure 5. Mean daily cycles of $\mathrm{H}_{2} \mathrm{O}$ flux (E) above the forest canopy in the three stations (Stn1, Stn2 and Stn3) during the pre-monsoon (Pre M), monsoon (M) and post-monsoon (Post M) seasons. The vertical bars denote the standard deviation from the mean of the corresponding hourly fluxes. 
values less than one throughout the year. Moreover, a significant lowering in Bowen ratio values during the night time showed that evaporation overruled transpiration in all the sites. As transpiration from the plant leaves and $\mathrm{CO}_{2}$ exchange by means of photosynthesis are a strongly coupled process, it is expected to observe a closely associated water vapour flux with that of $\mathrm{CO}_{2}$ flux (Mildenberger et al. 2009). Since we have detected a spatial variability of $\mathrm{CO}_{2}$ flux along with a constant $\mathrm{H}_{2} \mathrm{O}$ flux, it further strengthens the fact that transpiration has a minor contribution towards the overall water vapour flux.

\subsection{Influence of species composition on the $\mathrm{CO}_{2}$ fluxes}

The month-wise variation in the averaged day time $\mathrm{CO}_{2}$ uptake followed the same trend in all the three sites; became maximum during March and then decreased in the monsoon months, again increased a bit in October-November and became minimum in December-January. This might be due to the fact that PAR was high during the pre-monsoon months and it decreased during the monsoon owing to the effect of dark clouds. Moreover, the scatter plots between the magnitude of day time $\mathrm{CO}_{2}$ uptake and photosynthetic photon flux obtained from the three towers were of similar nature (figure 6). The relationship between the two parameters was best defined by a trend line of an exponential curve ( $R^{2}$ ranging from 0.51 to 0.60$)$. Other atmospheric factors like ambient temperature, relative humidity and $\mathrm{CO}_{2}$ mixing ratios did not have any relationship with $\mathrm{CO}_{2}$ flux. Therefore, the main reason that can be attributed to the difference in magnitude of $\mathrm{CO}_{2}$ uptake over the year is the varying photosynthetic efficiency of the species composition.

The photosynthetic efficiency of homogeneous mono-species vegetation is easier to assess and compare, but in this case the plant cover in all the three sites are randomly heterogeneous. The mixed vegetation cover in these sites includes almost eight to ten different mangrove species in varying proportion. The most challenging part of this study was to find out the site specific dominance of the species and their relative abundance. It was observed that five to six species contributed more than $90 \%$ of the canopy cover. The relative abundance found in Stn1 was of the order: A. marina $(33 \%)>A$. alba $(28 \%)>$ E. agallocha $(18 \%)>B$. gymnorhiza $(11 \%)>P$. paludosa (5\%), whereas in Stn3, it was in the sequence: A. officinalis $(37 \%)>A$. rotundifolia $(23 \%)>A$. corniculutum $(17 \%)>E$. agallocha $(15 \%)>$ P. paludosa $(4 \%)$. Though we could not perform the quadrat analysis in Stn2, it
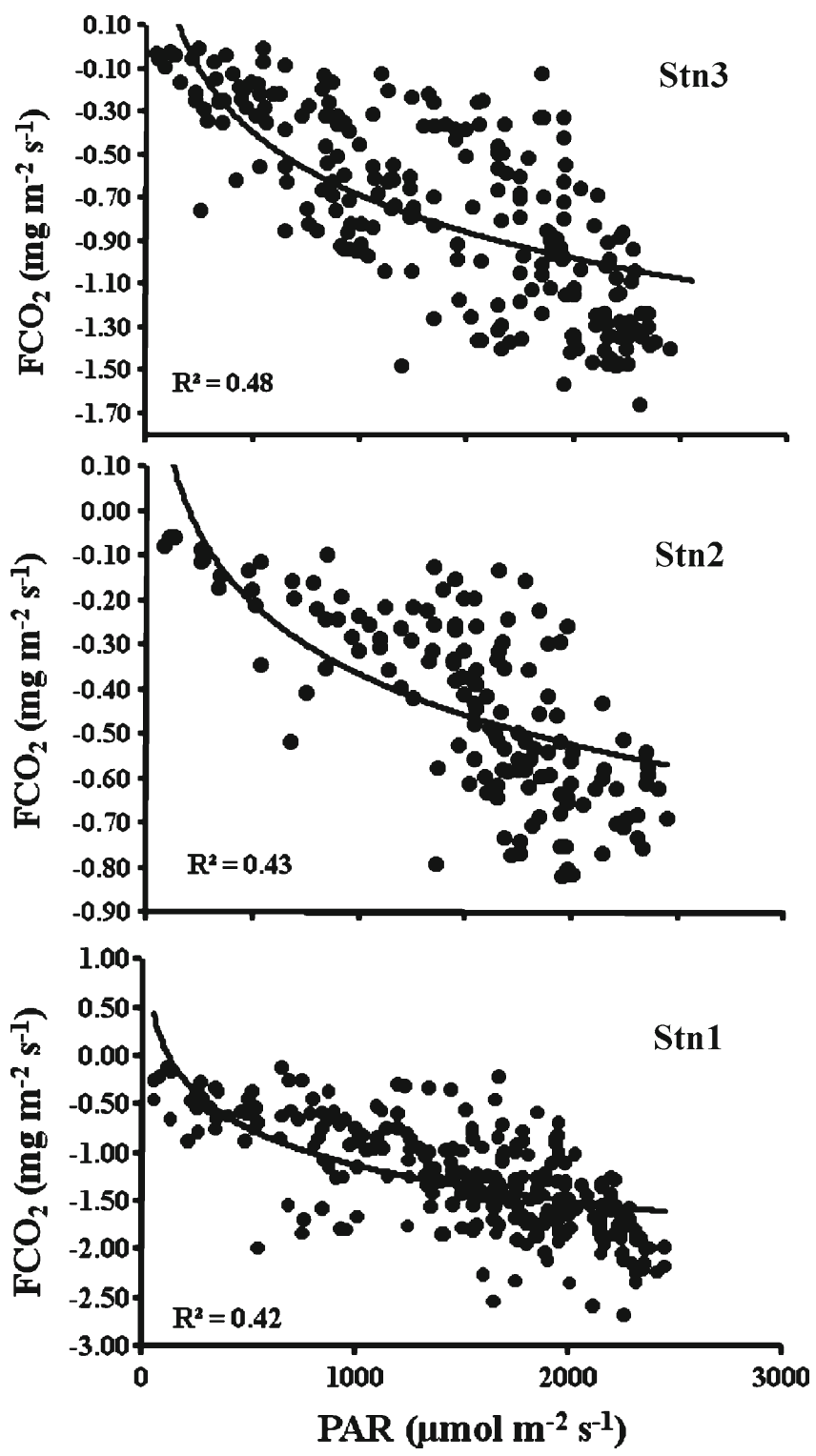

Figure 6. Relationship between the magnitude of day time $\mathrm{CO}_{2}$ influx $\left(\mathrm{F}_{\mathrm{CO}_{2}}\right)$ and photosynthetic photon flux (PAR) in the three stations (Stn1, Stn2 and Stn3) for the entire study period. The curves are non-linear least square fits for an exponential function.

was clearly visible from the tower, that the adjacent vegetation cover is principally dominated by $P$. paludosa. On the basis of eye estimation, it was roughly assessed that $P$. paludosa comprises almost $50 \%$ of the vegetation cover followed by $A$. marina, with the association of $A$. rotundifolia and A. corniculutum.

Nandy (Datta) and Ghose (2001) carried out an exhaustive study on the dominant mangrove species of the Indian Sundarbans identifying the inter-specific variation in the rate of photosynthesis and water use efficiency. According to them (among the species found to be dominant in the present study sites), A. marina has the highest photosynthetic rate $\left(11.8 \mu \mathrm{mol} \mathrm{m} \mathrm{m}^{-2} \mathrm{~s}^{-1}\right)$ and the 
lowest in case of $P$. paludosa $\left(3.69 \mu \mathrm{mol} \mathrm{m} \mathrm{m}^{-2} \mathrm{~s}^{-1}\right)$. Based on the relative abundance of species in the three sites and the photosynthesis efficiency tabulated in the paper of Nandy (Datta) and Ghose (2001), a weighed average was calculated for each site. The $\mathrm{CO}_{2}$ uptake potential for $\mathrm{Stn} 1$ was estimated to be the highest $\left(9.43 \mu \mathrm{mol} \mathrm{m} \mathrm{m}^{-2} \mathrm{~s}^{-1}\right)$, followed by $\operatorname{Stn} 3\left(7.25 \mu \mathrm{mol} \mathrm{m} \mathrm{m}^{-2} \mathrm{~s}^{-1}\right)$ and the least was observed in $\operatorname{Stn} 2\left(4.34 \mu \mathrm{mol} \mathrm{m} \mathrm{m}^{-2} \mathrm{~s}^{-1}\right)$. The annual mean day time $\mathrm{CO}_{2}$ flux above the canopy was found to correlate in the same order. The abundance of $A$. marina in Stn1 has led to the increased $\mathrm{CO}_{2}$ uptake throughout the year, and $P$. paludosa being short and stunted in structure and having much lesser photosynthetic rate compared to other species has attributed to the low $\mathrm{CO}_{2}$ flux recorded in Stn2. Moreover, the canopy density measured in bimonthly intervals (in Stn1 and Stn3) showed that it ranged between 74 and $81 \%$ in Stn1 and between 65 and $72 \%$ in Stn3. No significant seasonal variation was detected in any of the sites during the sampling. The Stn2 though could be surveyed, it was clearly visible from the tower that the forest was not that dense compared to Stn1 and Stn3. Hence it could be inferred from the present analysis that the maximum flux at Stn1 could be due to the combined effect of species diversity having greater $\mathrm{CO}_{2}$ sequestration potential and higher canopy density.

\section{Conclusion}

During the annual study, $\mathrm{CO}_{2}$, water vapour, sensible and latent heat fluxes were measured above the forest canopy with the main intention to characterize the spatial variability in the trace gas fluxes and identifying the factors regulating the flux. $\mathrm{CO}_{2}$ fluxes above the forest canopy showed significant spatial variability. Overall, the spatial distribution of the dominant species along with their relative abundance in each site strongly correlated with the magnitude of day time $\mathrm{CO}_{2}$ influx. Amongst all the micrometeorological variables studied, like atmospheric temperature, pressure, relative humidity and photosynthetic photon flux, it was only photosynthetic photon flux which showed a strong exponential relationship with the day time $\mathrm{CO}_{2}$ flux towards the biosphere. Our results further indicate that the variability in utilization of the photosynthetic photon flux together with the canopy density mainly determines the $\mathrm{CO}_{2}$ uptake potential of each site. From the measured differences in Bowen ratio between day and night times along with its spatial non-variance, it could be concluded that evaporation played major contribution in the water vapour fluxes compared to transpiration.

\section{Acknowledgements}

The authors are grateful to National Remote Sensing Centre, (NRSC), Department of Space, Government of India for funding the research work. A Chanda is grateful to Department of Science and Technology, Govt. of India for providing the INSPIRE fellowship.

\section{References}

Aubinet M, Berbigier P, Berndorfer C, Cescatti A, Feigenwinter C, Granier A, Grünwald T, Havrankova K, Heinesch B, Longdoz B, Marcolla B, Montagnani L and Sedlak P 2005 Comparing $\mathrm{CO}_{2}$ storage and advection conditions at night at different CARBOEUROFLUX sites; Bound.-Layer. Meteorol. 116 63-94.

Baldocchi D D, Hicks B B and Meyers T P 1988 Measuring biosphere-atmosphere exchanges of biologically related gases with micrometeorological methods; Ecology 69 1331-1340.

Barrett K 1998 Oceanic ammonia emissions in the Europe and their trans boundary fluxes; Atmos. Environ. 32(3) $381-391$.

Beer C, Reichstein M, Tomelleri E, Ciais P, Jung M, Carvalhais N, Rödenbeck C, AltafArain M, Baldocchi D, Bonan G B, Bondeau A, Cescatti A, Lasslop G, Lindroth A, Lomas M, Luyssaert S, Margolis H, Oleson K W, Roupsard O, Veenendaal E, Viovy N, Williams C, IanWoodward F and Papale D 2010 Terrestrial gross carbon dioxide uptake: Global distribution and covariation with climate; Science 329 834-838.

Borges A V, Djenidi S, Lacroix G, Theate J, Delille B and Frankignoulle M 2003 Atmospheric $\mathrm{CO}_{2}$ flux from mangrove surrounding waters; Geophys. Res. Lett. 30(11) $1-4$.

Bouillon S, Rivera-Monroy V H, Twilley R R and Kairo J G 2009 Mangroves; In: The management of natural coastal carbon sinks (eds) Laffoley D d'A and Grimsditch G (IUCN, Gland, Switzerland), 15p.

Duke N C, Ball M C and Ellison J C 1998 Factors influencing the biodiversity and distributional gradients in mangroves; Global Ecol. Biogeog. Lett. 7 27-47.

Foken T 2006 Angewandte Meteorologie-Mikrometeorologische Methoden; Springer, Berlin, 2. Auflage, 325 S.

Ganguly D, Dey M, Mandal S K, Dey T K and Jana T K 2008 Energy dynamics and its implication to biosphereatmosphere exchange of $\mathrm{CO}_{2}, \mathrm{H}_{2} \mathrm{O}$ and $\mathrm{CH}_{4}$ in a tropical mangrove forest canopy; Atmos. Environ. 42 4172-4184.

Lerman A 1979 Geochemical processes: Water and sediment environment, John Wiley, New York.

Lindroth A, Grelle A and Morén A-S 1998 Long-term measurements of boreal forest carbon balance reveal large temperature sensitivity; Global Change Biol. 4 443-450.

Magnani F, Mencuccini M, Borghetti M, Berbigier P, Berninger F, Delzon S, Grelle A, Hari P, Jarvis P G, Kolari P, Kowalski A S, Lankreijer H, Law B E, Lindroth A, Loustau D, Manca G, Moncrieff J B, Rayment M, Tedeschi V, Valentini R and Grace J 2007 The human footprint in the carbon cycle of temperate and boreal forests; Nature 447 849-851.

Meiresonne L, Sampson D A, Kowalski A S, Janssens I A, Nadeshdina N, Cermák J, Van Slycken J and Ceulemans R 2003 Water flux estimates from a Belgian Scots pine stand: A comparison of different approaches; J. Hydrol. $270230-252$. 
Mildenberger K, Beiderwieden E, Hsia Y-J and Klemm O $2009 \mathrm{CO}_{2}$ and water vapour fluxes above a subtropical mountain cloud forest - The effect of light conditions and fog; Agric. For. Meteorol. 149 1730-1736.

Misson L, Baldocchi D D, Black T A, Blanken P D, Brunet Y, Curiel Yuste J, Dorsey J R, Falk M, Granier A, Irvine $\mathrm{M} R$, Jarosz $\mathrm{N}$, Lamaud $\mathrm{E}$, Launiainen $\mathrm{S}$, Law B E, Longdoz B, Loustau D, McKay M, Paw U K T, Vesala T, Vickers D, Wilson K B and Goldstein A H 2007 Partitioning forest carbon fluxes with overstory and understory eddy-covariance measurements: A synthesis based on FLUXNET data; Agric. For. Meteorol. 144 14-31.

Mukhophadhya S K, Jana T K, De T K and Sen S 2000 Measurement of exchange of $\mathrm{CO}_{2}$ in mangrove forest of Sundarbans using micrometeorological method; Trop. Ecol. 41 57-60.

Mukhophadhya S K, Biswas H, Das K L, De T K and Jana T K 2001 Diurnal variation of carbon dioxide and methane exchange above Sundarbans mangrove forest, in NW coast of India; Indian J. Mar. Sci. 30 70-74.

Mukhophadhya S K, Biswas H, De T K, Sen B K, Sen S and Jana T K 2002 Impact of Sundarban mangrove biosphere on the carbon dioxide and mixing ratios at the NE coast of Bay of Bengal, India; Atmos. Environ. 36 629-638.
Nandy (Datta) P and Ghose M 2001 Photosynthesis and water-use efficiency of some mangroves from Sundarbans, India; J. Plant Biol. 44 213-219.

Noe S M, Kimmel V, Hüve K, Copolovici L, PortilloEstrada M, Püttsepp Ü, Jõgiste K, Niinemets Ü, Hörtnagl L and Wohlfahrt G 2011 Ecosystem-scale biosphereatmosphere interactions of a hemiboreal mixed forest stand at Järvselja, Estonia; Forest Ecol. Manag. 262 71-81.

Pilegaard K, Hummelshøj P, Jensen N O and Chen Z 2001 Two years of continuous $\mathrm{CO}_{2}$ eddy-flux measurements over a Danish beech forest; Agric. For. Meteorol. 107 29-41.

Ray R, Ganguly D, Chowdhury C, Dey M, Das S, Dutta M K, Mandal S K, Majumdar N, De T K, Mukhopadhyay S K and Jana T K 2011 Carbon sequestration and annual increase of carbon stock in a mangrove forest. Atmos. Environ. 45 5016-5024.

Reich P B 2010 The carbon dioxide exchange; Science $\mathbf{3 2 9}$ 774-775.

Stull R B 1988 An introduction to boundary layer meteorology (Dordrecht, Boston, London: Kluwer Academic Publishers).

Wesely M L and Hicks B B 1977 Some factors that affect the deposition rates of sulfur dioxide and similar gases on vegetation; J. Air Pollut. Control. Assoc. 27 1110-1116. 